Nina Živančević

\title{
Artificial Intelligence vs. Natural Ignorance
}

\section{and other tales from the 'Cabinet' of Rancière's Ignorant Schoolmaster}

316.7:004.7

316.774:001

DOI $10.18485 / \mathrm{fdu}$ dhkum.2021.ch17

\section{Introduction}

I started pondering about the problems imposed by the development of Artificial Intelligence (AI) more deeply when I read Dennis Scimeca's rather benign article 'How virtual reality developers are using brain science to trick you' in the beginning of 2016. The author spoke of a certain Kimberly Voll, a Ph.D. computer scientist and a specialist in Artificial Intelligence, as he commented on her work: "You may doubt that you'll ever fall for the illusion of virtual reality, but your brain is already working against you" (Scimeca, 2016). Allegedly, Dr Voll was developing the puzzle game Fantastic Contraption as she knew how our brain worked, and subsequently explained how it was specifically affected by Virtual Reality (VR).

We have historically, particularly in games, really tried to bring the player into that experience. We have spent time taking flat screens and trying to pull people into those screens. With VR we throw all of that out, because in many respects we are literally putting the person in the game, or in the experience. (Voll, per Scimeca, 2016)

The author then proceeds with explaining us the qualities of our brain and how it works: 
The key to this door is to understand the tools and senses that our brain uses to figure out what is real (in the so-called real world) and then - give those tools and senses the same data, but in the virtual world. The brain is also gullible and easy to fool. Have you ever seen an optical illusion where two objects are actually the same size, but one looks larger than the other? Your brain falls for it every time. The way a VR developer fools your brain into thinking that a virtual space is real, is by knowing what tools your brain uses to construct reality, and then giving your brain the same information, but presented in virtual reality. VR developers in a simulation give your brain all the building blocks it needs to say "this is real". (Scimeca, 2016)

Because your brain can be so thoroughly fooled into thinking that the virtual is the real, players may need to be warned about the content that awaits them in the simulation. Not warning people that a VR game is scary and then giving them a jump scare can make people really upset.

\section{Traps of the AI and VR}

I would say that "upset" is a small word - a "jump scare" can drive people mad. I sank into a deep depression when a two year virtual correspondence between me and a CIA high profile thug wore off. I was a victim of a virtual game I didn't even know I was a part of. One day I simply started to see virtual things more clearly, I started making a certain distinction between "the real" and the virtual being served to me (Živančević, Leger, 2016).

However, the pertinent question here is - how do we start learning to see? How do we see things in their true light, lit by the artificial light of our extended self, that is, a computing object at hand? Gene Tracy, a professor of Physics and an expert in Plasma Wave Theory claims that the most brilliant scientific insight depends, like the everyday faculty of sight, on distinguishing meaningful signals from among random ones. When Galileo looked at the Moon through his new telescope in early 1610, he immediately 
grasped that the shifting patterns of light and dark were caused by the changing angle of the Sun's rays on a rough surface. Learning to see, professor Tracy says, is not an innate gift; it is an iterative process, always in flux and constituted by the culture in which we find ourselves and the tools we have to hand (Tracy, 2018: 242).

In Galileo's time, the Florentines were masters of perspective, using shapes and shadings on a two-dimensional canvas to evoke three-dimensional bodies in space. Galileo was a friend of artists and someone who in his youth might have considered becoming one himself. He believed with a kind of religious fervor that the creator of the world was a geometer. Galileo likely imbibed these mathematically deep methods of representation based on the projective geometries of light rays. When Galileo looked at the face of the Moon, he had no trouble understanding that on the moon, mountaintops first catch fire with the rising Sun while their lower slopes remain in darkness. When we consider often complex scientific observations we find them contingent much like human vision itself.

Assemblies of machines that detect the undetectable, from gravitational waves in the cosmos, to the minute signals within human cells, rely on many forms of "sight". By exploring vision as a metaphor for scientific observation, and scientific observation as a type of seeing, we might ask: how does prior knowledge about the world affect what we observe? If prior patterns are essential for making sense of things, how can we avoid falling into well-worn channels of perception? And most importantly, how can we learn to see in genuinely new ways? And how do we learn to see something that is truly new and unexpected? If the brain is a taxonomizing engine, anxious to map the things and people into familiar categories, then true learning must always be disorienting. Learning shifts the internal constellation of the firings of our nerves, the spark of thought itself. This mental flexibility is an inheritance, hard-won over eons by our ancestors, and it serves as a good metaphor for how scientists can learn to see with new mechanical-eyes.

Perhaps Jacques Rancière (2004) had musings similar to Gene Tracy's, concerning the unattended and unlimited possibilities of the learning process as such, when he wrote his treatise on the learning process of languages. It was all about a university course 
taught by an "ignorant master", Joseph Jacotot, in that distant 1818. By teaching the subject-matter to his Dutch Louvain students in French, the language they did not even understand, Jacotot entered the specific domain of the science of learning. His epistemology comfortably claimed that if it is clear that while seeing and hearing might be believing, it is also true that believing affects our understanding of what we hear and see, and learn for the first time.

But how are we to believe that everything that we hear and see for the first time should have some true cognitive value? Or that we should believe in the intrinsic value of things optically created for us on the side of AI? The danger of believing something which has a high potential to harm us really undermines its true cognitive worth; perhaps the effort of trusting AI should be placed into the realm of cognitive bias, notwithstanding our ability to protect ourselves from it. And what are the areas of potential danger where $\mathrm{AI}$ is likely to intervene?

Well, all the areas of human interaction are exposed to the contemplation of the virtual, and as William S. Burroughs said in an interview I conducted, "whenever people use something, soon enough they ab-use it" (Burroughs, 1986). VR is undergoing rapid new developments and as the tech preachers trumpet an imminent explosion in accessibility, artists are exploring the darker contours of these responsive environments. Traditionally speaking, the artists would be the first to rebel against algorithms, as they have a general tendency to easily become enraged throughout the ages.

Not long ago, a study was published on Art and VR, entitled "Deep Dive" where the invited visionary artists and thinkers such as Douglas Coupland, Daniel Birnbaum, Paul Mc Carthy and Marina Abramovic tried to examine the technology and the questions it raises about artifice and resemblance, perception and truth, omnipresence and repression, alienation and existence. Douglas Coupland made a general complaint that his real world was much grimmer than his experiences in VR. He sees VR as the logical end point of a data-bombardment process that started with Gutenberg and accelerated with radio, TV, then the Internet - until data became addictive, and "our need for it has grown the way addicts need bigger and bigger fixes to get high" (Coupland, 2017). 
The artist says "our days are largely spent behind screens, with greatly reduced somatic experience, and our memories of the day come from those screens that are fire-hosing data into our brains. We now calibrate our sense of time passing by how much information we absorbed that day. Data is the new time and, by extension, the cloud is the new infinity. And VR is a kind of temporal accelerator... VR is as much data as the human brain can handle... VR is your brain flying straight up the Y Asymptote" (Coupland, 2017).

Some think that when fully established, VR will change the way we inhabit this planet. Similar to the invention of electricity, life without VR would be intolerable, especially on a sexual level; also it would be intolerable without the experience which provides fight or flight experiences, as well as the habitual experiences of porn and gaming that we got used to with VR.

However, notwithstanding the fact that VR is really harsh on our vestibular system and the reptile cortex, the artist reminds us of the positive fact, that whenever a new technology triumphs, it also allows the technology it has rendered obsolete to become an art form: VR could, allegedly allow for a golden age of internet art, synthetic arts, etc. The real limitation of VR is that it presents itself as an amniotic dream state, with which we go into a state of fundamental solitude. All the communal aspects of art are gone here as it shows to us it's masturbatory aspect, namely- it has its solipsistic aspect of a tendency to isolate. Are we a Chinese philosopher Zhuangzi who dreamed that he was a butterfly or, are we that butterfly who dreams that it is a philosopher Zhuangzi?

Douglas Coupland exclaimed appropriately: "if Surrealism happened today it would be over in a week" (Coupland, 2017). Or perhaps it would last over the weekend. But one cannot walk faster than a brain wave, otherwise he gets totally burnt by the algorithm, and if a person is self-indulgent and likes the leap into the "aloburns", he may even exclaim like Jordan Wolfson, Jeff Coons or Marina Abramovich: it is better than real life!

However, most of the artists cringe from any further advancement of algorithms; there have been great moments of techno-optimism in art, from Futurism around 1910, to Group Zero and Net art more recently. However, most of the intelligent artists cringe 
at the possibility of being qualified as potentially obsolete. They neither like to be linked to commercialism and the entertainment industry. There is a bigger respect for the Situationists and Walter Benjamin then in the heyday of their existence, untainted by glitch.

In an interview Paul Virillio had given for the French newspaper Le Liberation as early as 1996, he appeared as a great visionary warning us against the "highways of information", where a possibility for the appearance of various accidents related to the acceleration of the world had already seemed enormous and inevitable. His vision was dark and filled with pessimism, but nonetheless seemed pertinent to us. It appeared at the times when his encounter with the world of Web was in its cradle, and before the real web adventure had fully kicked off. In the dialogue with the journalist, Virilio said that "he was willing to put on his face the mask of Cassandra, because there was an enormous amount of publicity related to the launch of the Windows 95 program at that time and he had to react to it" (Virilio, 1996). In fact, his outcry was not directed against technology and the technological progress as such, but against their advertising. He was refusing to enter the "mythology of communication", which seemed to be a meta-story taking advantage of the "highway of information". Obsessed with the problem of speed and its harmful consequences on our entire civilization, Virilio declared fear of the shrinking of the world as such - as the speed, propelled by the modems, was advancing in it.

Virilio's prophecies about the world appear to us much more contemporary now, than the outdated menus of the Windows 95 program. In his sermon, he did not deny the Internet's role in the process of the democratization of knowledge, but the philosopher neatly refused to neglect the historical origin of the new technologies. He remembered that it was the Security Department of the U.S. Defense who installed the first net of the nets in the beginning of the 1960s. And for Virilio, the cold war and the Mail $99+$, possibly a nuclear one - were being replaced with the "war on information" championed by the Net. He described to that effect the troubling dystopia of our contemporary Internet: "on one hand, allegedly, we had the investment in advertising executed by Time Warner, Microsoft or Disney corporations; these coupled, on the 
other hand, with the secret information control organized by National Security Agency and other forms of military powers" (Virilio, 1996). Some of his concerns were overtly displayed to us in 2013 after the famous 'Snowden Affair', but we should not forget that Virilio had launched his warnings as early as in the 1990s.

In the interview (Towards a Total Accident) which I conducted with him for the journal Erewhon 2 (1995), he clearly stated "The world is, in fact, controlled by the National Security Agency, and Internet and NSA are intertwined and interdependent, but I wonder to what degree they are going to agree with one another? And to what point will the Internet resist the occupation of the National Security Agency? In the Pentagon, and also perhaps throughout Europe in future everything will be connected and in the hands of those who rule the world" (Virilio, 1995).

However, what Paul Virilio had named "Internet", it really means Web to us now, that is, the big interconnection which helps us, general folks, connect to the Net of the nets. The philosopher recognized the web pilot as a bait for a citizen to enter the dark net held by the hands of the American government system. "The Internet is just an advertising tool which will lead us to the future highways of information; it is a sort of publicity, very attractive, on a discount, predestined to attract those who previously had certain doubts as to the origin of the worldwide information" (Virilio, 1995). Virilio did not believe in the Democratic intentions of the Internet, and his critique of it was a part of the more general critique of the speeding up of the world as such.

I definitely don't believe in the "automated democracy", as I rather believe in reflection and not in reflex, an impulse in the world. New technology is into the conditioning of men and in that sense it is a suspicious thing which believes in an opinion poll and a survey. (Virilio, 1996)

If Virilio's theory of catastrophe and a general accident seems pertinent to us today, it is also due to the fact that a number of the accidents related to the Internet, which he had predicted a while ago, have come true. The incidents in question have surely 
damaged, if not entirely destroyed, our earlier optimism we cherished for technology. Somewhat like Burroughs a bit earlier in that decade, Paul Virilio exclaimed "When we invent an object at the same time we invent its accident" (Virilio, 1996). When we build a ship we also contribute to creating a shipwreck, such was the case with the Cambridge Analytica scandals, WikiLeaks, etc.

The first thing that arises here is the question: in the age of WikiLeaks, total Security checkups and an overwhelming surveillance, who would dare to write something private on the Net, exchange the most intimate thoughts and feelings with an unknown person and then even publish that correspondence? Kathy Acker comes to my mind first - lonely musings of the First Lady of the American postmodern letters, her musings sent to an anarchisttheorist, Wark McKenzie. However, in the very preface to their book I'm Very Into You, the editor Chris Kraus (2015) noticed that if Acker had lived to see their correspondence in print, she would have never approved it.

And I approved of mine with my anonymous correspondent, although many sleepless nights went into my musings over it should I trash the whole thing, remove it from my cortex? Or just edit it, change its entire grammar, style and contents, see it in print? Then, perhaps, the worst of the William Burroughs type of trials would follow, where the contents of the book would be judged according to the local taste for morality, shady ethics or local literary mores? I had all this on my mind and yet, I approved of it, applying some minimal amount of editing to 500 pages of correspondence, which officially lasted from February 2015 through the end of June 2016.

Some critics say that this fiction / correspondence was a brand new literary genre, with totally new idiosyncratic style and outlook. I do not know if I myself can make such claims on the book which went into print, but the whole writing process went very smoothly and quickly as my correspondent and I applied the socalled Orpheus and Eurydice method to it. The entire narrative plot of Orpheus and Eurydice, which is a love story - a crush fiction of a sort, served as a cyber-metaphor for our writing method. In the original myth Orpheus, a poet and a musician is followed by all 
the animals as he performs so beautifully; he goes back to the dark Web underworld to look for his dead Eurydice - with the intention to return her to the world of the living. He puts her on her back, navigates across the Hades and the Styx rivers of Web and is likely to succeed his mission under only one condition - that he never turns back to give her a real look.

What interested me here, in our version of that ancient story, was its direct application to our writing procedure: my correspondent and I would write our emails dangerously quick, without "turning our heads back" or reflecting too much on them. We were rushing and advancing through time and the Net - so that we wouldn't turn back and lose our "Eurydice", the hidden meaning or purpose of our task for good. On this particular journey, the authors Eurydice and Orpheus were exchanging roles - sometimes Orpheus would be in the role of the leader, and when he would start losing energy, Eurydice would slip into his role, put him on her back and continue the journey as Orpheus. Some of their funny, anonymous camaraderie bordering on an innate understanding of one another, penetrates this book. And much in the line of the Everyman's walk through life, this correspondence can be read as an ancient travelogue. It could be read as a dialogue coined out of dust that one finds under the hooves of the horses belonging to those medieval Troubadours and Minnesingers who had set out to conquer Jerusalem. In their midnight musings and while at rest - they had nothing else to do but make one another laugh: the Crusade was cruel, they had no future and anyways, they were going to die in it. But they had this grit, a sort of gift of laughing into the face of the Leaking Web while making each other laugh. That's how our book came into existence or at least- that's how I tend to see it.

\section{Conclusion}

If I were to bring my observations in regards to Net to conclusion, I would certainly mention the fact that in the four centuries since Galileo bent to look through his optic tube, the human brain 
has not changed all that much. Rather it would be useful to notice that the current revolution comes from our new tools, new tubes, new theories and new methods of analysis made possible by new hardware. Detectors make visible what was previously hidden, and the learning process involves ever more powerful computer algorithms that seek patterns in those new observations.

As Daston argues in his book The image of objectivity, scientific observation does mean parsing the world into pieces, and also naming those pieces through shared idealizations (Tracy, 2018). Today it is done using a data stream from a global network of detectors aided by smart algorithms to assist in our naming, learning to navigate an information flood that each second dwarfs the amount of data collected by Galileo, for example. But the real question remains - can the machines really give us new eyes so that we can see things that have been there all along but in a new way?

\section{References}

Acker, K. and McKenzie, W. (2015) I'm Very Into You: Correspondence 1995-1996. New York: Semiotext(e).

Coupland, D. (2017) “Deep Dive, Art and VR”, ARTFORUM, Vol. 56, No 3. https://www.artforum.com/print/201709/deep-dive-71773

Lütticken, S. (2019) “Toward a Terrestrial”. e-flux journal, vol. 103. https:// www.e-flux.com/journal/103/291974/toward-a-terrestrial/

Rancière, J. (2004) Le maître ignorant. Paris: Essai (Poche).

Scimeca, D. (2016) "How VR Developers are using brain science to trick you", Scientific American, Vol. 315, Issue 3. https://www.dailydot. com/parsec/gdc-2016-the-psychology-of-vr/

Tracy, G. (2018) "Learning to See", American Scientist, vol. 106, no. 4, p. 242.

Virilio, P. (1996) “Virilio cyberésistant”, Libération, Paris, 10 May 1996.

Virilio, P. and Živančević, N. (1995) “Towards a Total Accident”, EREWHON 2, pp. 47-54.

Živančević, N. and Léger, M. J. (2016) Cmok to You Too: A Correspondence. Brooklyn: Punctum Books. 


\section{Nina Živančević \\ Univerzitet Nova Sorbona 3; Univerzitet Sorbona 1, Pariz, Francuska \\ VEŠTAČKA INTELIGENCIJA I PRIRODNA GLUPOST}

Šta su novi horizonti kulture, odakle oni potiču i u kom pravcu se oni, na kraju kreću? Digitalni prostor je omogućio ljudskim bićima da se njime kreću neverovatnom brzinom, istovremeno ih ohrabrujući da vrše potpunu regrupaciju toga prostora. Kompanije koje prodaju proizvode Velike Mreže i koje ih prodaju najimućnijim magnatima pretvaraju polis Interneta u pijacu prodajnih objekata. I dok nam budućnost tako postaje sve određenija, primećujemo da monopol na informaciju predstavlja pravu novu opasnost za naše sfere delovanja. Kako kompjuterska moć postaje sve veća, gotovo neograničena, u polju kibernetičke stvarnosti, uporedo sa njom raste do sada neistraženi potencijal korupcije svih delova naše stvarnosti.

Prema MekKenzi Vorku „informacija želi da bude slobodna, ali je svugde vidimo već u lancima“. Ovu izreku već dvostruko primenjujemo pri istraživanju beskrajno kopirane i beskrajno primenljive digitalne ontologije koja mora izaći iz svog sopstvenog ograničenja i zatvorenosti. Ili kao što primećuje Sven Litiken: „Veštačka inteligencija je deo onih, po Bergsonu, već gotovih gorućih problema koji se baziraju na neispitanim pretpostavkama i institucionalnim planovima za koje donosimo rešenja napravljena od iste problematične materije... Ne trebaju nam autonomne mašine već svojevrsna tehnika rukovanja njima, tehnika koja je u okviru pokreta za autonomnost (oslobađanje) čoveka" (Lütticken, 2019).

Ključne reči: digitalnost, komunikacija, brzina, neuro-plastificiranost, mozak, monopolna informacija 